\title{
1 Virological characteristics of SARS-CoV-2 vaccine breakthrough infections in health
} 2 care workers

4 Marc C. Shamier ${ }^{1}$, Alma Tostmann ${ }^{2}$, Susanne Bogers ${ }^{1}$, Janet de Wilde ${ }^{1}$, Jeroen IJpelaar ${ }^{1}$, Willemijn A. van 5 der Kleij ${ }^{3}$, Herbert de Jager ${ }^{3}$, Bart L. Haagmans ${ }^{1}$, Richard Molenkamp ${ }^{1}$, Bas. B. Oude Munnink ${ }^{1}$, Carsten 6 van Rossum ${ }^{2}$, Janette Rahamat-Langendoen ${ }^{2}$, Nannet van der Geest ${ }^{5}$, Chantal P. Bleeker-Rovers ${ }^{4}$, 7 Heiman Wertheim ${ }^{2}$, Marion P.G. Koopmans ${ }^{1}$, Corine H. GeurtsvanKessel ${ }^{1}$

9 Affiliations

$10{ }^{1}$ Department of Viroscience, Erasmus Medical Center, Rotterdam, The Netherlands

$11{ }^{2}$ Department of Medical Microbiology, Radboud Centre for Infectious Diseases, Radboud university

12 medical center, Nijmegen, The Netherlands

$13{ }^{3}$ Department of Occupational Health Services, Erasmus Medical Center, Rotterdam, Netherlands.

$14{ }^{4}$ Department of Internal Medicine, Radboud Centre for Infectious Diseases, Radboud university medical 15 center, Nijmegen, The Netherlands

$16{ }^{5}$ Department of Occupational Health, Radboud university medical center, Nijmegen, The Netherlands

17

18 Corresponding authors:

19 email c.geurtsvankessel@erasmusmc.nl 
medRxiv preprint doi: https://doi.org/10.1101/2021.08.20.21262158; this version posted August 21, 2021. The copyright holder for this preprint (which was not certified by peer review) is the author/funder, who has granted medRxiv a license to display the preprint in perpetuity. It is made available under a CC-BY-ND 4.0 International license .

\section{Abstract}

22 Background: SARS-CoV-2 vaccines are highly effective at preventing COVID-19-related morbidity and

23 mortality. As no vaccine is $100 \%$ effective, breakthrough infections are expected to occur.

24 Methods: We analyzed the virological characteristics of 161 vaccine breakthrough infections in a 25 population of 24,706 vaccinated healthcare workers (HCWs), using RT-PCR and virus culture.

26 Results: The delta variant (B.1.617.2) was identified in the majority of cases. Despite similar Ct-values, we

27 demonstrate lower probability of infectious virus detection in respiratory samples of vaccinated HCWs

28 with breakthrough infections compared to unvaccinated HCWs with primary SARS-CoV-2 infections.

29 Nevertheless, infectious virus was found in $68.6 \%$ of breakthrough infections and Ct-values decreased

30 throughout the first 3 days of illness.

31 Conclusions: We conclude that rare vaccine breakthrough infections occur, but infectious virus shedding 32 is reduced in these cases. 
medRxiv preprint doi: https://doi.org/10.1101/2021.08.20.21262158; this version posted August 21, 2021. The copyright holder for this preprint (which was not certified by peer review) is the author/funder, who has granted medRxiv a license to display the preprint in perpetuity.

It is made available under a CC-BY-ND 4.0 International license .

\section{Introduction}

Once COVID-19 vaccines became available, health care workers (HCWs) were among the first groups to be vaccinated and reach high vaccine coverage. Registered vaccines have been highly effective in preventing clinically significant coronavirus disease 2019 (COVID-19), caused by severe acute respiratory syndrome coronavirus 2 (SARS-CoV-2) ${ }^{1}$, and have shown to reduce the incidence of infections ${ }^{2,3}$. However, mild breakthrough infections in a small percentage of vaccine recipients have been described ${ }^{4-9}$ which is not surprising as none of the registered vaccines will provide sterile immunity against infection $^{10-13}$. In a setting of mass vaccination, the BNT162b2 vaccine was highly effective (92\%) at preventing infection from 7 days after the second dose $\mathrm{e}^{14}$, but a recent study from Israel described vaccine breakthrough infections in 39 health care workers vaccinated with the BNT162b2 mRNA vaccine. The alpha variant was identified as the main causative strain and a majority of cases presented low Ct-values (<30), indicating probable infectivity ${ }^{4}$. For the single dose Ad26.COV2.S adenoviral vector vaccine, a phase IV study reported a $76.1 \%$ effectiveness to prevent infection from 14 days after vaccination ${ }^{15}$. The effectiveness against infection with the delta (B.1.617.2) variant was $88 \%$ for the BNT162B2 vaccine and $67 \%$ for the ChAdOx1 vaccine, moderately lower than against infection with the alpha (B.1.1.7) variant ${ }^{16}$.

Up to present, little is known about the virological kinetics of SARS-CoV-2 breakthrough infections, and the role of the vaccinated host in the transmission cycle. Better understanding of the dynamics of

52 breakthrough infections is essential to define infection prevention and (public) health policies during the next phase of the pandemic. In this study, we report the virological findings of 161 vaccine breakthrough

54 infections occurring from April to July 2021 in the Netherlands. The infections occurred in HCWs working in two tertiary care hospitals, who were immunized with various mRNA and viral vector vaccines. as a proxy for infectivity. 
medRxiv preprint doi: https://doi.org/10.1101/2021.08.20.21262158; this version posted August 21, 2021. The copyright holder for this preprint (which was not certified by peer review) is the author/funder, who has granted medRxiv a license to display the preprint in perpetuity.

It is made available under a CC-BY-ND 4.0 International license .

\section{Results}

A total of 161 fully vaccinated HCWs diagnosed with COVID-19 by PCR were included in this study. In accordance with case definitions defined by the Centers for Disease Control and Prevention, infections were classified as breakthrough infections if the date of the first positive SARS-CoV-2 RT-PCR was more than 14 days after completion of all recommended vaccine doses ${ }^{17}$. Cases with symptom onset $<14$ days after the last vaccine dose and cases with a previous positive test $<45$ days prior were not considered breakthrough infections. In parallel with a surge in cases in the general Dutch population ${ }^{18}$, an increased incidence of breakthrough infections in HCWs was observed in July 2021. In 126 samples a SARS-CoV-2

67 lineage could be identified, $90.5 \%$ of these showed presence of the delta variant. The mean age of the HCWs with a breakthrough infection was 25.5 years and $91 \%$ were less than 50 years old (Table 1). All

69 infections were mild and did not require hospital admission. The individuals were vaccinated between January and May 2021 with either an mRNA vaccine or a viral vector vaccine. Table 1 shows the

71 distribution of vaccines among all HCWs and among the HCWs with breakthrough infections. Although

72 the data may imply an overrepresentation of Ad26.COV2.S and BNT162b2 vaccine recipients among the

73 cases, this study was not designed to compare vaccine effectivity. The indication to receive a certain

74 vaccine was not random and data on risk factors for exposure were not recorded, therefore potential

75 confounders could not be adjusted for.

76 Table 1 shows the distribution of Ct-values of the breakthrough infections, as a proxy for the

77 nasopharyngeal viral load. Ct-values were significantly lower in symptomatic breakthrough infections $(\mu$

$78=23.2)$ than in asymptomatic breakthrough infections $(\mu=26.7)$, corresponding to higher viral loads $(p=$

790.022 , t-test). In symptomatic vaccinated HCWs, the Ct-values decreased significantly throughout the first

80 days from symptom onset and were lowest on the third day of illness (Figure 1A). There were no 81 statistically significant differences in Ct-values between HCWs immunized with the 4 different vaccines. 
medRxiv preprint doi: https://doi.org/10.1101/2021.08.20.21262158; this version posted August 21, 2021. The copyright holder for this preprint (which was not certified by peer review) is the author/funder, who has granted medRxiv a license to display the preprint in perpetuity.

It is made available under a CC-BY-ND 4.0 International license .

82 Furthermore, the time since the administration of the last vaccine dose showed no clear relationship with

83 Ct-values $\left(R^{2}=0.02, p=0.13\right.$, linear regression $)$.

84 Subsequently, RT-PCR positive swabs were tested for the presence of infectious virus using cell culture.

85 As a reference, we used the (first positive) samples from mild primary infections that occurred in the same

86 cohort of HCWs prior to the onset of vaccination, these infections were primarily caused by SARS-CoV-2

87 D614G. The mean Ct-value upon diagnosis was similar between these two groups: 24.6 (15.3 - 33.9) for vaccinated HCWs and 24.2 (14.53 - 33.8) for unvaccinated HCWs ( $p=0.53$, t-test) (Figure 1B). The SARS-

89 CoV-2 culture of nasopharyngeal swabs was positive in $68.6 \%$ of vaccinated HCWs versus $84.9 \%$ of

unvaccinated HCWs with primary infections $(p=0.005$, t-test). As the probability of culture positivity

91 depends on viral load ${ }^{19}$, this was corrected for using a probit regression model with both viral load and

92 vaccination status as predictors. Figure $1 \mathrm{C}$ shows the probability of a positive culture for a given viral load in vaccinated and unvaccinated HCWs. A positive vaccination status significantly decreased the probability of culture positivity ( $p=0.002$, Wald test).

\section{Discussion}

In this study we assessed the virological kinetics of mild COVID-19 breakthrough infections upon

97 immunization with several vaccines. Our data support that the SARS-CoV-2 infectious virus shedding is lower in vaccinated individuals with breakthrough infections (caused by primarily the delta variant) than in unvaccinated individuals with primary infections (caused by SARS-CoV-2 D614G). Nevertheless, virus culture was positive in $68.6 \%$ of breakthrough infections and Ct-values decreased throughout the first three days of illness. Despite the reduced viral viability, the infectivity of individuals with breakthrough

102 infections should not be neglected. 
medRxiv preprint doi: https://doi.org/10.1101/2021.08.20.21262158; this version posted August 21, 2021. The copyright holder for this preprint (which was not certified by peer review) is the author/funder, who has granted medRxiv a license to display the preprint in perpetuity.

It is made available under a CC-BY-ND 4.0 International license .

105

106

107

108

109

110

111

112

113

114

115

116

117

118

119

120

121

122

123

124

125

126

127

128

rather than whole (infectious) virions and is therefore not an optimal indicator of infectivity ${ }^{19}$. Ct-values are sometimes used to differentiate between phases of infection, but the definition of a cut-off value is complicated, due to the large variety of assays and clinical samples. Considering these limitations of RTPCR, demonstrating viral viability through replication in cell culture is currently considered the best proxy to demonstrate infectious virus in a clinical specimen ${ }^{20,21}$. We and others previously showed that the viability of SARS-CoV-2 depends on several factors among which the severity of disease, timing of sampling, the type of specimen and presence of antibodies ${ }^{19,22}$. To our knowledge this is the first study to report on virus cultures in COVID-19 vaccine breakthrough infections. Although reduced immune responses may likely account for breakthrough infections, further studies are needed to investigate whether these are still able to reduce infectious virus shedding.

Obviously, the use of virus culture has its limitations as well: it is a laborious method only performed in specialized BSL-3 laboratories and therefore not widely applicable. In addition, lack of standardization of methods (e.g. the cell line used) still hampers interchangeability of results between laboratories. Nevertheless, an experimental animal study on SARS-CoV-2 transmission recently confirmed a strong correlation between transmission and virus culture ${ }^{23}$.

To study the effect of vaccination on infectivity, it would be preferable to compare infections occurring in vaccinated and unvaccinated individuals during the same time period, to minimize the impact of different SARS-CoV-2 variants. Due to the high vaccine coverage in HCW, we diagnosed very few infections in unvaccinated HCWs. For this reason, we used infections prior to the onset of vaccination as a reference. Although the predominant SARS-CoV-2 variant differed between groups, the groups were similar with respect to demographic characteristics, severity of disease, testing algorithms and Ct-values upon diagnosis. The study participants comprise a population immunized with several vaccines, which reflects the current situation in many countries. This study was not designed to detect differences in vaccine effectiveness, as HCWs who received different vaccines also differed with respect to demographic 
medRxiv preprint doi: https://doi.org/10.1101/2021.08.20.21262158; this version posted August 21, 2021. The copyright holder for this preprint (which was not certified by peer review) is the author/funder, who has granted medRxiv a license to display the preprint in perpetuity. It is made available under a CC-BY-ND 4.0 International license.

129 characteristics. The frequency of breakthrough infections in the different groups was likely influenced by 130 variables that were not controlled for.

131 Phase IV studies have confirmed that vaccination is highly effective at preventing COVID-19-related 132 morbidity and mortality ${ }^{2,14,15}$ although vaccine effectiveness will never reach $100 \%$. Our study supports 133 the excellent effectiveness of vaccination in preventing severe SARS CoV-2 related disease, but also 134 demonstrates that vaccinated individuals can still acquire infection and carry infectious virus. Although 135 symptomatic vaccinated individuals should be tested to further reduce the chance of virus transmission 136 to individuals at risk for severe disease, further studies are needed to assess whether the decreased 137 infectious virus shedding in breakthrough infections also lowers the chance of virus transmission. 
medRxiv preprint doi: https://doi.org/10.1101/2021.08.20.21262158; this version posted August 21, 2021. The copyright holder for this preprint (which was not certified by peer review) is the author/funder, who has granted medRxiv a license to display the preprint in perpetuity.

It is made available under a CC-BY-ND 4.0 International license .

\section{Methods}

\section{Study population}

Data were collected and analyzed anonymously from HCWs of two tertiary care centers in the Netherlands (Erasmus University Medical Center, Rotterdam and Radboud University Medical Center, Nijmegen), together employing over 25,000 HCWs. Since April 2020, approximately 1900 symptomatic HCWs presenting to the occupational health services department were enrolled into a prospective cohort study ${ }^{24}$. Symptomatic HCWs underwent questioning and SARS-CoV-2 RT-PCR testing, complemented by tracing and testing of contacts, resulting in detection of asymptomatic cases. Any infections diagnosed by external laboratories were reported by the department of the respective employee. In both centers, immunization of HCWs commenced in January 2021 with the BNT162b2 mRNA vaccine (Pfizer-BioNTech), prioritizing physicians and nurses working directly with COVID-19 cases. The majority of HCWs received either the mRNA-1273 (Moderna) or Ad26.COV2.S (Janssen) vaccines and a minority was vaccinated with ChAdOx1 (AstraZeneca Oxford) (Table 1). The indication of the different vaccines was based on availability and professional role. Throughout the study period, all HCWs with symptomatic breakthrough infections followed institutional infection prevention guidelines and resumed their professional activities only after full recovery. HCWs with asymptomatic breakthrough infections remained in home isolation for at least 3 days. We compared virological characteristics of first RT-PCR positive samples collected from HCWs with breakthrough infections to first RT-PCR positive samples from the same cohort of HCWs prior to the onset of vaccination. The breakthrough infections occurred between April and July 2021, the primary infections occurred between April and December 2020 and were primarily caused by SARS-CoV-2 D614G. The two groups did not differ with respect to demographic characteristics and testing algorithms remained unchanged. 
medRxiv preprint doi: https://doi.org/10.1101/2021.08.20.21262158; this version posted August 21, 2021. The copyright holder for this preprint (which was not certified by peer review) is the author/funder, who has granted medRxiv a license to display the preprint in perpetuity.

It is made available under a CC-BY-ND 4.0 International license .

\section{RT-PCR for the detection of SARS-CoV-2 RNA}

163

164

SARS-CoV-2 RT-PCR tests were performed on nasopharyngeal swabs, using the SARS-CoV-2 test on a Cobas ${ }^{\circledR} 6800$ system (Roche Diagnostics) in Erasmus MC and using the Aurora Flow (Roche Diagnostics) in Radboud Medical Center. Using a formula based on E-gene calibration curves, cycle threshold (Ct) values were converted to viral load in $\log _{10}$ RNA copies/mL. This conversion method was previously validated ${ }^{25}$.

\section{Typing of SARS-CoV-2 variants using RT-PCR or next generation sequencing}

All positive samples were analyzed for the presence of mutations indicative of variants of concern, either by next generation sequencing or by the use of variant-specific RT-PCR tests (VirSNiP assays 53-0799 and 53-0807, TIB Molbiol, Berlin, Germany) using a SYBR Green melting curve protocol. These assays screen for the presence of HV69/70 deletion, N501Y, E484K, K417T/K417N and P681R mutations. The results were interpreted based on the genomics of the SARS-CoV-2 lineages circulating at the time of this study. The combination of the HV69/70 deletion and N501Y mutation was considered indicative for the Alpha variant (B.1.1.7). A K417N/E484K/N501Y profile was considered indicative for the Beta variant (B.1.351), K417T/E484K/N501Y for the Gamma variant (P.1) and P681R for the Delta variant (B.1.617.2).

\section{Virus culture}

Virus culture was performed on all samples collected in the Erasmus Medical Center, by inoculating Vero cells (clone 118) as previously described ${ }^{19}$. All cultures were performed in twofold, with one replicate for immunofluorescence analysis after acetone fixation at $48 \mathrm{~h}$ of incubation. The second replicate was microscopically examined for the presence of cytopathic effect daily for 2 weeks. Viral culture was considered negative if no cytopathic effect was observed after 14 days of incubation. To investigate how the probability of the binary outcome (culture positivity) depends on viral load and vaccination, the culture results were analyzed using probit regression. 
medRxiv preprint doi: https://doi.org/10.1101/2021.08.20.21262158; this version posted August 21, 2021. The copyright holder for this preprint (which was not certified by peer review) is the author/funder, who has granted medRxiv a license to display the preprint in perpetuity. It is made available under a CC-BY-ND 4.0 International license .

\section{Statistical analysis}

185 All statistical analyses was performed using R Statistical Software version 4.1.1 (Foundation for Statistical

186 Computing, Austria) and STATA statistical software program version 13.1 (Statacorp, USA).

\section{Ethical approval}

188 This study was approved by Radboud university medical center Committee on Research Involving Human

189 Subjects and the Erasmus Medical Center Medical Ethics Committee. All samples were collected following

190 routine institutional COVID-19 testing guidelines, the participants were not subject to any procedures for

191 the purpose of this study and all data were anonymized prior to analysis. 
medRxiv preprint doi: https://doi.org/10.1101/2021.08.20.21262158; this version posted August 21, 2021. The copyright holder for this preprint (which was not certified by peer review) is the author/funder, who has granted medRxiv a license to display the preprint in perpetuity.

It is made available under a CC-BY-ND 4.0 International license.

194 Table 1. Characteristics of health care workers with SARS-CoV-2 vaccine breakthrough infections

\begin{tabular}{|c|c|c|c|c|c|}
\hline & \multicolumn{3}{|c|}{ HCWs with breakthrough infection } & \multicolumn{2}{|c|}{ All HCWs } \\
\hline & & $\mathrm{N}$ & $\%$ & $\mathrm{~N}$ & $\%$ \\
\hline \multirow[t]{4}{*}{ Vaccine } & BNT162b2 & 37 & 23.0 & 2537 & 11.4 \\
\hline & mRNA-1273 & 38 & 23.6 & 11321 & 51.1 \\
\hline & Ad26.COV2.S & 71 & 44.1 & 7379 & 33.3 \\
\hline & ChAdOX1 & 15 & 9.3 & 932 & 4.2 \\
\hline \multirow[t]{3}{*}{ Symptomatic } & Yes & 136 & 84,5 & & \\
\hline & No & 21 & 13,0 & & \\
\hline & Unknown & 4 & 2,5 & & \\
\hline \multirow[t]{5}{*}{ Age } & $<25$ & 71 & 44,1 & & \\
\hline & $25-35$ & 56 & 34,8 & & \\
\hline & $35-50$ & 20 & 12,4 & & \\
\hline & $50-60$ & 10 & 6,2 & & \\
\hline & $>60$ & 4 & 2,5 & & \\
\hline \multirow[t]{5}{*}{ Variant } & Alpha & 10 & 6,2 & & \\
\hline & Beta & 1 & 0,6 & & \\
\hline & Gamma & 1 & 0,6 & & \\
\hline & Delta & 114 & 70,8 & & \\
\hline & Unknownt & 35 & 21,7 & & \\
\hline \multirow[t]{7}{*}{ Ct-value } & $<15$ & 2 & 1,2 & & \\
\hline & $15-20$ & 34 & 21,1 & & \\
\hline & $20-25$ & 45 & 28,0 & & \\
\hline & $25-30$ & 29 & 18,0 & & \\
\hline & $30-35$ & 15 & 9,3 & & \\
\hline & $>35$ & 3 & 1,9 & & \\
\hline & Unknownt & 33 & 20,5 & & \\
\hline
\end{tabular}

195

196 rCt-values and variant analysis were not available for health care workers whose tests were performed by external laboratories 
A

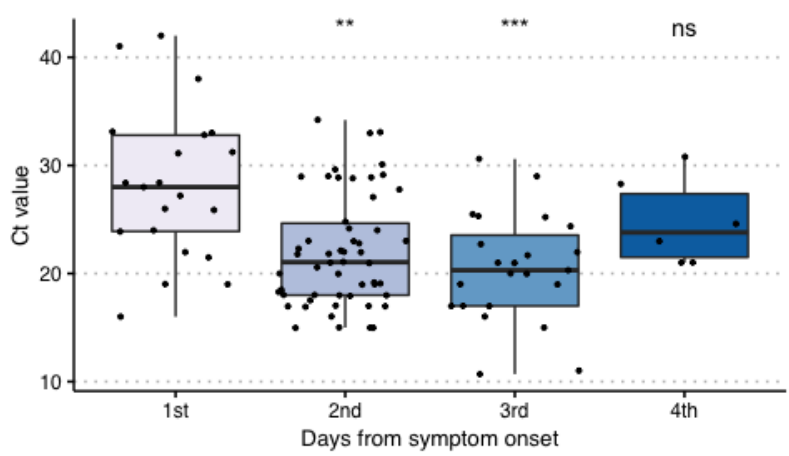

B

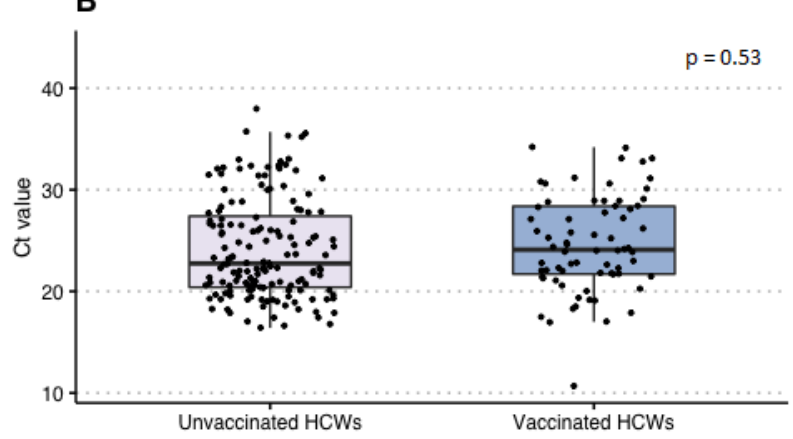

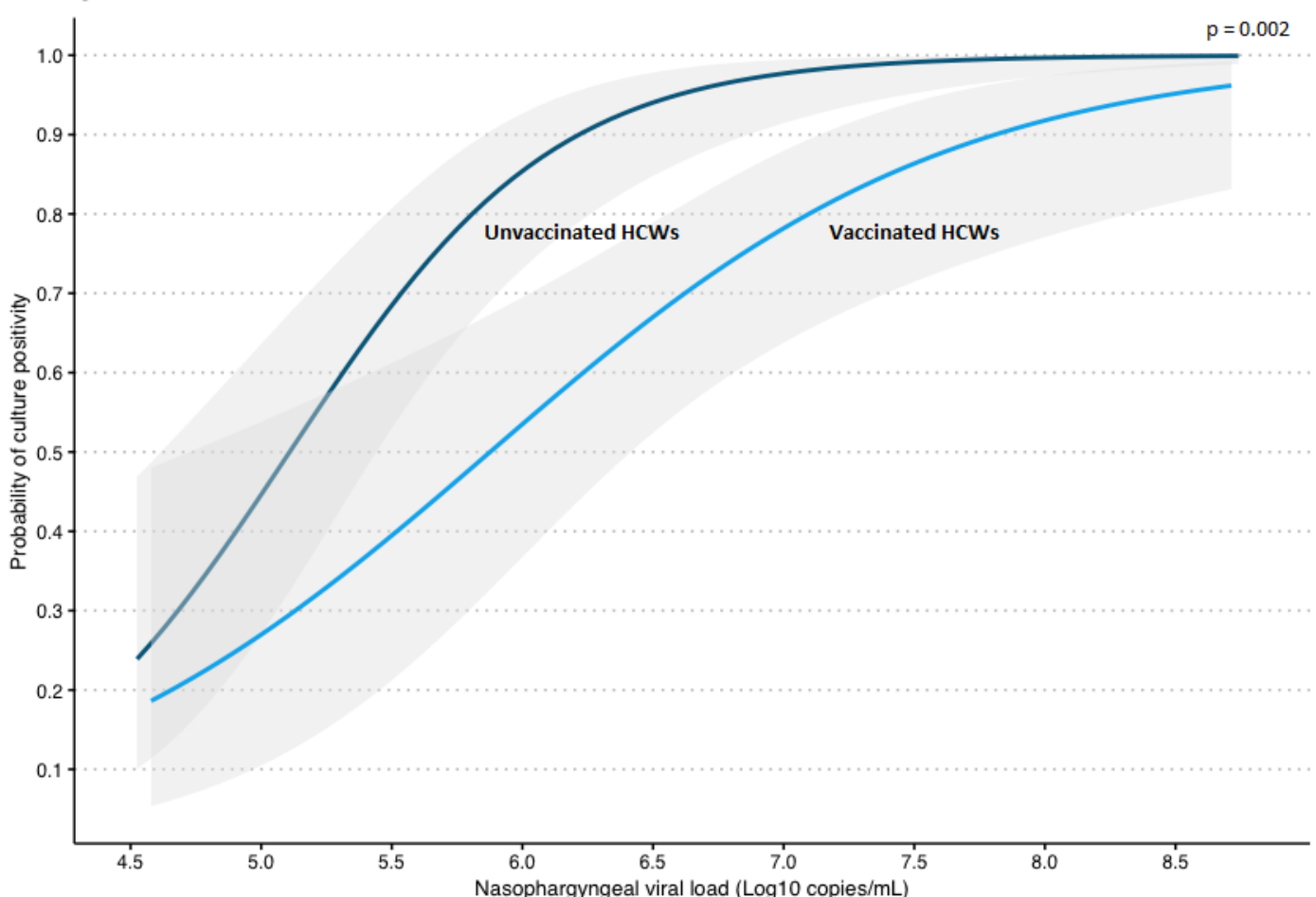

Figure 1. SARS-CoV-2 culture positivity and Ct-values in nasopharyngeal samples of health care workers with SARS-CoV-2 breakthrough infections. (A) Ct-values by day from symptom onset (B) Ct-values of HCWs with vaccine breakthrough infections (primarily Delta) compared to Ct-values of HCWs with primary infections (primarily D614G) (C) Probability of culture positivity by nasopharyngeal viral load (Probit Analysis), comparing HCWs with vaccine breakthrough infections (primarily Delta) to HCWs with primary infections (primarily D614G) 
medRxiv preprint doi: https://doi.org/10.1101/2021.08.20.21262158; this version posted August 21, 2021. The copyright holder for this preprint (which was not certified by peer review) is the author/funder, who has granted medRxiv a license to display the preprint in perpetuity.

It is made available under a CC-BY-ND 4.0 International license .

\section{References}

1. Zhou P, Yang XL, Wang XG, et al. A pneumonia outbreak associated with a new coronavirus of probable bat origin. Nature 2020;579:270-3.

2. Abu-Raddad L, Chemaitelly H, Butt AA, National Study Group for C-V. Effectiveness of the BNT162b2 Covid-19 Vaccine against the B.1.1.7 and B.1.351 Variants. N Engl J Med 2021;385:187-9.

3. Lopez Bernal J, Andrews N, Gower C, et al. Effectiveness of the Pfizer-BioNTech and OxfordAstraZeneca vaccines on covid-19 related symptoms, hospital admissions, and mortality in older adults in England: test negative case-control study. BMJ 2021;373:n1088.

4. Bergwerk M, Gonen T, Lustig Y, et al. Covid-19 Breakthrough Infections in Vaccinated Health Care Workers. N Engl J Med 2021.

5. Kroidl I, Mecklenburg I, Schneiderat P, et al. Vaccine breakthrough infection and onward transmission of SARS-CoV-2 Beta (B.1.351) variant, Bavaria, Germany, February to March 2021. Euro Surveill 2021;26.

6. McEwen AE, Cohen S, Bryson-Cahn C, et al. Variants of concern are overrepresented among postvaccination breakthrough infections of SARS-CoV-2 in Washington State. Clin Infect Dis 2021.

7. Rana K, Mohindra R, Pinnaka L. Vaccine Breakthrough Infections with SARS-CoV-2 Variants. N Engl J Med 2021;385:e7.

8. Tyagi K, Ghosh A, Nair D, et al. Breakthrough COVID19 infections after vaccinations in healthcare and other workers in a chronic care medical facility in New Delhi, India. Diabetes Metab Syndr 2021;15:1007-8.

9. Vignier N, Berot V, Bonnave N, et al. Breakthrough Infections of SARS-CoV-2 Gamma Variant in Fully Vaccinated Gold Miners, French Guiana, 2021. Emerg Infect Dis 2021;27.

10. Absalon J, Koury K, Gruber WC. Safety and Efficacy of the BNT162b2 mRNA Covid-19 Vaccine. Reply. N Engl J Med 2021;384:1578.

11. Baden LR, El Sahly HM, Essink B, et al. Efficacy and Safety of the mRNA-1273 SARS-CoV-2 Vaccine. N Engl J Med 2021;384:403-16.

12. Polack FP, Thomas SJ, Kitchin N, et al. Safety and Efficacy of the BNT162b2 mRNA Covid-19 Vaccine. N Engl J Med 2020;383:2603-15.

13. Voysey M, Clemens SAC, Madhi SA, et al. Safety and efficacy of the ChAdOx1 nCoV-19 vaccine (AZD1222) against SARS-CoV-2: an interim analysis of four randomised controlled trials in Brazil, South Africa, and the UK. Lancet 2021;397:99-111.

14. Dagan N, Barda N, Kepten E, et al. BNT162b2 mRNA Covid-19 Vaccine in a Nationwide Mass Vaccination Setting. N Engl J Med 2021;384:1412-23.

15. Corchado-Garcia J, Puyraimond-Zemmour D, Hughes T, et al. Real-world effectiveness of Ad26.COV2.S adenoviral vector vaccine for COVID-19. medRxiv 2021:2021.04.27.21256193.

16. Lopez Bernal J, Andrews N, Gower C, et al. Effectiveness of Covid-19 Vaccines against the B.1.617.2 (Delta) Variant. N Engl J Med 2021;385:585-94.

17. COVID-19 Vaccine Breakthrough Infections Reported to CDC - United States, January 1-April 30, 2021. MMWR Morb Mortal Wkly Rep 2021:792-3.

18. RIVM. Epidemiologische situatie van SARS-CoV-2 in Nederland (27 juli 2021). National Institute for Public Health and the Environment 2021.

19. van Kampen JJA, van de Vijver D, Fraaij PLA, et al. Duration and key determinants of infectious virus shedding in hospitalized patients with coronavirus disease-2019 (COVID-19). Nat Commun 2021;12:267.

20. Folgueira MD, Luczkowiak J, Lasala F, Perez-Rivilla A, Delgado R. Prolonged SARS-CoV-2 cell culture replication in respiratory samples from patients with severe COVID-19. Clin Microbiol Infect 2021;27:88691. 
medRxiv preprint doi: https://doi.org/10.1101/2021.08.20.21262158; this version posted August 21, 2021. The copyright holder for this preprint (which was not certified by peer review) is the author/funder, who has granted medRxiv a license to display the preprint in perpetuity. It is made available under a CC-BY-ND 4.0 International license.

21. Jefferson T, Spencer EA, Brassey J, Heneghan C. Viral cultures for COVID-19 infectious potential assessment - a systematic review. Clin Infect Dis 2020.

22. Wolfel R, Corman VM, Guggemos W, et al. Virological assessment of hospitalized patients with COVID-2019. Nature 2020;581:465-9.

23. Sia SF, Yan LM, Chin AWH, et al. Pathogenesis and transmission of SARS-CoV-2 in golden hamsters. Nature 2020;583:834-8.

24. Geers D, Shamier MC, Bogers S, et al. SARS-CoV-2 variants of concern partially escape humoral but not T-cell responses in COVID-19 convalescent donors and vaccinees. Sci Immunol 2021;6.

25. Schuit E, Veldhuijzen IK, Venekamp RP, et al. Diagnostic accuracy of rapid antigen tests in asymptomatic and presymptomatic close contacts of individuals with confirmed SARS-CoV-2 infection: cross sectional study. BMJ 2021;374:n1676. 
medRxiv preprint doi: https://doi.org/10.1101/2021.08.20.21262158; this version posted August 21, 2021. The copyright holder for this preprint (which was not certified by peer review) is the author/funder, who has granted medRxiv a license to display the preprint in perpetuity.

$$
\text { It is made available under a CC-BY-ND } 4.0 \text { International license. }
$$

\section{Acknowledgements}

David van de Vijver, Jolanda Kreeft-Voermans, Amber Weevers, Anoushka Comvalius, Djenolan van Mourik and Michael van der Voorden are gratefully acknowledged for their technical and analytical contributions. 